\title{
Editorial
}

\section{Mesenchymal Stem Cell Therapy for Lung Diseases: Oasis or Mirage?}

\author{
Paschalis Ntolios Sam M. Janes \\ Centre for Respiratory Research, University College London, London, UK
}

There is a growing clamor from patients and clinicians to see cell therapies enter clinical trials for lung parenchymal diseases such as acute lung injury or idiopathic pulmonary fibrosis. So why do scientists remain skeptical? Is this caution justified in the face of a continuing flurry of murine experiments showing that intravenously administered mesenchymal stem cells (MSCs) attenuate various lung injury models?

This caution of course reflects our ignorance of how this therapy works. A patient being shepherded towards a new cellular therapy has the right to ask several questions and expect an educated answer. At what point in my disease course should I have the cells? How many cells do I need? Do I need my own cells or someone else's? Do I need multiple treatments? Do I need the cells at all, or just what they secrete? And of course the obvious question: how does this therapy work?

Can we as a community answer these questions? No.

MSCs act as a source of adipocytes, cartilage and bone cells and are thought to form a niche for hematopoiesis. They are easily harvested from bone marrow but can also be retrieved from adipose tissue, umbilical cord and blood and rapidly expand in vitro making them attractive as cell therapies [1].

At the beginning of the century considerable hype was around the ability of MSCs to differentiate into epithelial cells and the possibility of using this multipotency to regenerate epithelial organs. In vivo studies, however, have faltered and if 'transdifferentiation' occurs at all, it is felt not to be clinically significant.

Despite this there is a growing body of evidence that supports the role of exogenously delivered MSCs attenuating many disease processes across many organs. In the lung this has focused around fibrotic and acute lung injury. A number of studies suggest their beneficial role is through interacting with and regulating the immune system. This has led to the first clinical studies of intravenously delivered MSCs for autoimmune diseases, including graft versus host disease, Crohn's disease, multiple sclerosis and systemic lupus erythematous with promising results [2-6].

Importantly MSCs appear to be immunoprivileged, expressing human leukocyte antigen and major histocompatibility complex (MHC) class I but not MHC class II [7] meaning MSCs should fail to elicit a T cell response even after allogeneic exposure [8]. This in theory enables the administration of allogeneic MSCs, eliminating the problems of extraction and culture of autologous cells from ill patients and allowing 'off-the-shelf products.

However, all may not be as it first appeared, and there are several new studies that challenge both the idea that MSCs are a potent inhibitor of immune responses $[9,10]$ and that they avoid immune surveillance. Indeed some studies show MSCs have no effect at all [11] and others that MSCs may even trigger further fibrosis [12].

\begin{tabular}{ll}
\hline KARGER & (c) 2013 S. Karger AG, Basel \\
0025-7931/13/0854-0279 \$38.00/0 \\
$\begin{array}{l}\text { Fax +41 61 306 } 1234 \\
\begin{array}{l}\text { E-Mail karger@karger.com } \\
\text { www.karger.com }\end{array}\end{array}$ & $\begin{array}{l}\text { Accessible online at: } \\
\text { www.karger.com/res }\end{array}$
\end{tabular}

Sam M. Janes, MD, PhD

UCL Respiratory, Lungs for Living Research Centre

University College London, Rayne Building

5 University Street, London WC1E 6JJ (UK)

E-Mail s.janes@ucl.ac.uk 
In this issue of Respiration, Lim et al. [13] present new data adding to the skepticism for off-the-shelf products. They compare the anti-inflammatory and antifibrotic effects of human MSCs (hMSCs) in immunocompromised (SCID) and immunocompetent (C57BL/6) mice after bleomycin lung injury. The study shows that hMSCs administered to immunodeficient SCID mice ameliorated some of the effects of bleomycin on physiological lung function parameters. In contrast, there was no benefit from hMSCs in bleomycin-damaged immunocompetent C57BL/6 mice. More exasperating still was that disease attenuation was not related to the levels of inflammatory cytokines after hMSCs administration. The authors suggest possible explanations for their findings - the first be- ing most likely that hMSCs were rejected after all by the immunocompetent C57BL/6 mice.

This study challenges the immunoprivileged status of MSCs accepting the possibility of MHC mismatch leading to rejection by the immunocompetent $\mathrm{C} 57 \mathrm{BL} / 6$ mice. In contrast, other MSCs have been shown to ameliorate bleomycin-induced injury in both immunocompetent and immunocompromised mice [14-16].

So when to go to clinical trials? No doubt we will know more in 5 years and more still in 10 years. Perhaps in 20 years we will have an idea of how to answer many of our patients' questions. But are we really going to wait until then?

\section{References}

1 Loebinger MR, Sage EK, Janes SM: Mesenchymal stem cells as vectors for lung disease. Proc Am Thorac Soc 2008;5:711-716.

2 Ciccocioppo R, Bernardo ME, Sgarella A, et al: Autologous bone marrow-derived mesenchymal stromal cells in the treatment of fistulising Crohn's disease. Gut 2011;60:788-798.

3 Connick P, Kolappan M, Crawley C, et al: Autologous mesenchymal stem cells for the treatment of secondary progressive multiple sclerosis: an open-label phase $2 \mathrm{a}$ proof-ofconcept study. Lancet Neurol 2012;11:150156.

4 Duijvestein M, Vos AC, Roelofs H, et al: Autologous bone marrow-derived mesenchymal stromal cell treatment for refractory luminal Crohn's disease: results of a phase I study. Gut 2010;59:1662-1669.

5 Le Blanc K, Frassoni F, Ball L, et al: Mesenchymal stem cells for treatment of steroid-resistant, severe, acute graft-versus-host disease: a phase II study. Lancet 2008;371:1579-1586.
6 Wang D, Zhang H, Liang J, et al: Allogeneic mesenchymal stem cell transplantation in severe and refractory systemic lupus erythematosus: 4 years experience. Cell Transplant 2012, E-pub ahead of print.

-7 Deans RJ, Moseley AB: Mesenchymal stem cells: biology and potential clinical uses. Exp Hematol 2000;28:875-884.

8 Rasmusson I, Ringdén O, Sundberg B, et al: Mesenchymal stem cells inhibit the formation of cytotoxic T lymphocytes, but not activated cytotoxic T lymphocytes or natural killer cells. Transplantation 2003;76:1208-1213.

-9 Waterman RS, Tomchuck SL, Henkle SL, et al: A new mesenchymal stem cell (MSC) paradigm: polarization into a pro-inflammatory MSC1 or an immunosuppressive MSC2 phenotype. PLoS One 2010;5:e10088.

10 Le Blanc K, Mougiakakos D: Multipotent mesenchymal stromal cells and the innate immune system. Nat Rev Immunol 2012;12: 383-396.

11 Aguilar S, Scotton CJ, McNulty, et al: Bone marrow stem cells expressing keratinocyte growth factor via an inducible lentivirus protects against bleomycin-induced pulmonary fibrosis. PLoS One 2009;4:e8013.
12 McNulty K, Janes SM: Stem cells and pulmonary fibrosis: cause or cure? Proc Am Thorac Soc 2012;9:164-171.

13 Lim R, Milton P, Murphy SV, et al: Human mesenchymal stem cells reduce lung injury in immunocompromised mice but not in immunocompetent mice. Respiration 2013;85: 332-341.

14 Murphy S, Lim R, Dickinson H, et al: Human amnion epithelial cells prevent bleomycin-induced lung injury and preserve lung function. Cell Transplant 2011;20:909-923.

15 Moodley Y, Ilancheran S, Samuel C, et al: Human amnion epithelial cell transplantation abrogates lung fibrosis and augments repair. Am J Respir Crit Care Med 2010;182:643651.

16 Moodley Y, Atienza D, Manuelpillai U, et al: Human umbilical cord mesenchymal stem cells reduce fibrosis of bleomycin-induced lung injury. Am J Pathol 2009;175:303-313. 